\title{
The Identification of Scientific Attitude on Biology Education Department in Plant Botany I
}

\author{
Sri Amintarti, Aulia Ajizah, Nurul Hidayati Utami \\ Biology Education Study Program \\ Universitas Lambung Mangkurat \\ Banjarmasin, Indonesia \\ nh.utami@gmail.com/nhu.utami@ulm.ac.id
}

\begin{abstract}
This study aims to describe the scientific attitude of students who took Plant Botany I course and to study scientific attitudes among male and female students. The study used a survey method for students whom participating in the Plant Botany I course listed on $\mathbf{2 0 1 7 / 2 0 1 8}$ academic year as many as 54 students. Data was obtained through questionnaires and observations of scientific attitudes during the course. The data was analyzed quantitatively and qualitatively according to the description. From the results of the study, it was shown that discovery is the highest score for scientific aspect and there is a difference of scientific attitude among male and female students in Plant Botany I course.
\end{abstract}

Keywords - scientific attitude, Gender, Plant Botany I

\section{INTRODUCTION}

The Plant Botany I course takes three credits with two credits ( $2 \times 50$ minutes) for conveying theories through face to face in class and one credit ( 1 x 50 minutes) praxis in the laboratory. Based on these facts, biology learning develops not only materials and understanding but also attitudes. This course aims to equalize the basic concepts of Cryptogamic Botany in students from various fields of taxonomic studies. Those courses examine the characteristics of Schyzophyta, Bryophyta, and Pteridophyta.

Hence, scientific attitudes should be developed by lecturers in class, especially for Plant Botany I because students are expected to be better prepared to take further courses. Science students, in general, have to internalize various scientific attitudes. Scientific attitude includes the following habits of thinking [1]

Based on the learning outcomes, achievement can be reached through learning. Students learning outcomes will change in behavior because it changes the cognitive, affective, and psychomotor. Learning outcomes have a broad domain so that scientific attitudes are part of the learning outcomes carried out by students.

In the class, students will desire to obtain information from trusted sources, avoid conclusions from limited evidence, and an attitude of openness to change the mind when other evidence is found.
Scientific attitudes is an ability or tendency to react that is consistent, rational and objective in a certain way to a new problem or situation [2]. Scientific attitudes include emotional attitudes and intellectual attitudes [3]. Ref [4] stated that "The scientific attitude is the attitude that scientists have in seeking and developing new knowledge." Therefore, scientific attitudes are the ability to react consistently, rationally, and objectively like what scientists have in seeking knowledge.

Literally, the scientific attitudes contain two meanings, namely attitude toward science and attitude of science [2]. Attitudes towards science refer to the inherent attitude after learning science, for example, considers science interesting to learn, boring, or difficult to understand. Emotional attitude is a basic attitude in the form of curiosity, perseverance, positive attitude towards failure to give up, and open minded to new experiences or other people's point of view. Intellectual attitude is an attitude based on intellectual and rational that is built continuously with the development of science process skills. Science process skill and scientific attitude correlate each other.

Scientific attitudes are the attitudes that scientists have in finding and developing new knowledge, such as objective facts, cautions, and responsibilities. Some scientific attitudes consist of open mindedness, curiosity, a judgement based on verified facts, ready to test and verify the conclusion, as well as faith in cause and effect relationship [1]. Scientific attitude as condition how to dispose of ideas, person, and environment to reduce intolerance, superstition, and guilty. Ref [4] Mentions many aspects of scientific attitude, for instance, curiosity, objectively to facts, caution, responsibility, critical thinking, open mindedness, and always want to research. Based on this point, the aspects of scientific attitudes are critical thinking, open mindedness, respect to the data/fact, critical thinking and discovery and perseverance.

Scientific attitude is a reflection of the development of scientific thinking and skills possessed by students. The aspects of the scientific attitude developed in science learning are presented in Table 1 . 
TABLE I. ASPECT AND INDICATOR OF SCIENTIFIC ATtitudes

\begin{tabular}{|c|c|}
\hline Aspect & Indicator \\
\hline \multirow{2}{*}{ Curiosity } & Enthusiastic seeking the answers \\
\hline & Attention to observed objects \\
\hline \multirow{3}{*}{$\begin{array}{l}\text { Respect to the } \\
\text { data/fact }\end{array}$} & $\begin{array}{l}\text { Enthusiastic about the science process } \\
\text { Objective/ honest to the data/ facts }\end{array}$ \\
\hline & Not manipulating the data \\
\hline & Not mixing facts and opinions \\
\hline \multirow{3}{*}{ Critical thinking } & Critically dubious friend's findings \\
\hline & Taking decisions according to facts \\
\hline & Not ignoring data even though it's small \\
\hline \multirow{3}{*}{ Discovery } & Showing different reports \\
\hline & Using facts as the base of conclusions \\
\hline & Changing opinions in response to facts \\
\hline \multirow[b]{2}{*}{ Perseverance } & Repeating the experiment \\
\hline & $\begin{array}{l}\text { Completing one activity even though the } \\
\text { classmates finish earlier }\end{array}$ \\
\hline
\end{tabular}

Scientific attitudes are important to be trained to students in the learning process because they play a role to determines the effectiveness and success about science. Students who have a negative thought about science will not be interest in science class.

At this point, this study is necessarily to conduct aiming to (1) describe the scientific attitude of students who took Plant Botany I course and (2) study difference scientific attitudes among male and female students.

\section{RESEARCH METHOD}

The study employed survey research. It used quantitative and qualitative approaches to categorize the scientific attitudes in every aspect. It was conducted on Biology Education Study Program of Faculty of Teacher Training, Universitas Lambung Mangkurat in Academic Year 2017/2018 who took the Plant Botany I in a number of 54 students. This study was conducted at the end of the even semester.

The collection of data and information was carried out with several techniques, namely by distributing questionnaires and observing the scientific attitudes directly. Data collection techniques by giving a questionnaire developed using a Likert scale and observation in the class during learning on Plant Botany I. Likert scale can be used to measure attitudes, opinions, and perceptions of a person or group about social phenomena. Observation of scientific attitudes was carried out during the study to see directly and recorded various behaviors during the practical work. This Observation was done without involving certain treatments.

The dimension and aspect of scientific attitude developed and prepared according to the basic competencies of lesson plan for lecturers.
The validity of the instrument used was content validity and construct validity for the scientific attitude questionnaire instrument. Content validity was done by asking the expert judgment. It was done by making a grid developed from deep theoretical studies. The content validity was carried out by: (1) making the instrument based on indicators; (2) comparing the contents of the instrument made with the program design specified, and (3) consulting the expert (Expert judgment).

The data was analyzed by descriptive statistic consisting of: (1). Scoring each item test, (2). Adding all aspects and indicators, (3). Making the frequency of each category suppressed by the formula, and (4). Analysis of the criteria will be categorized into five.

$$
p=\frac{f}{N} X 100 \%
$$

$\mathrm{F}$ is the frequency being searched for the percentage, $\mathrm{N}$ is the total number of frequency. $\mathrm{P}$ is percentage points. establishment of graduation standards or competency achievement [5]. The five categories are displayed in Table 2

TABLE II. CRITERIA FOR ACHIEVING COMPETENCY STANDARD

\begin{tabular}{|l|l|}
\hline \multicolumn{1}{|c|}{ Average Score } & \multicolumn{1}{c|}{ Category } \\
\hline $90 \% \leq x$ & Very high \\
\hline $75 \% \leq x<90 \%$ & High \\
\hline $60 \% \leq x<75 \%$ & Medium \\
\hline $40 \% \leq x<60 \%$ & Low \\
\hline$x<40 \%$ & Very low \\
\hline
\end{tabular}

\section{RESULTS AND DISCUSSION}

The results of this study are summarized in Table 3 .

TABLE III. The Students SCIENTIFIC ATtitude In Plant Botany I COURSE

\begin{tabular}{|l|l|l|}
\hline \multicolumn{3}{|c|}{ Scientific attitude } \\
\hline \multicolumn{1}{|c|}{ Aspect } & \multicolumn{1}{|c|}{$\begin{array}{c}\text { Average } \\
\text { score }\end{array}$} & Category \\
\hline Curiosity & 70.74 & Medium \\
\hline Respect to the data or fact & 71.82 & Medium \\
\hline Discovery & 75.17 & High \\
\hline Critical Thinking & 67.05 & Medium \\
\hline Perseverance & 62.23 & Medium \\
\hline
\end{tabular}

Plant Botany I aims to understand the characteristics and description of cryptogamic plant, so this course requires perseverance and accuracy in observing objects of practical work. Based on the data, the highest category is discovery. It occurred when the learning took place; the students were enthusiastic about finding the answers to the existing phenomenon. Some students are more courageous to expressing the ideas during learning in class. Based on the observation, most students rewrote their conclusion in the guidance book and captured their findings by picture. They 
tried to show different reports when finishing their practical work and connecting to their practical work.

They also learned about critical thinking skill which consists of three aspects namely analysis, synthesis, and evaluation [6]. Based on the learning process, the students demonstrate critical thinking by conducting experiments in groups and not copied other group experimental data. Some students repeated their practical work more than three times to ensure their data. Most students confirmed their findings or opinions to the assistance or lecturer.

The aspect of respect to facts or data was categorized medium. The students collected the data by observation using a microscope to observe small creatures. Most of them used their own data based on the observation, and few of them copied the data for other groups when they respect to the data/fact. They would then conclude it.

The aspect of curiosity was categorized medium. The students found out new things by reading books, discussing with group friends, and asking lots of questions. Besides that, the students were enthusiastic when they were going to do the experiment and observation. The scientific attitude is a curiosity to know about one's environment; the belief that nothing can happen without a cause and those occurrences that seem strange and mysterious can always be explained by natural causes [7].

Perseverance aspect is such as not feeling bored of conducting an investigation and willing to repeat an experiment whose results are doubtful. The students did not have to stop doing activities. However, in reality, most of the students gave up for their experiment. So, for helping the student, the assistance or lecturer should be in class. Based on the category, the perseverance aspect is the lowest aspect. The results can be seen in Table 4.

TABLE IV. The SCIENTIFIC AtTitude Students AMONG MALE AND FEMALE STUDENT

\begin{tabular}{|l|l|l|}
\hline \multicolumn{3}{|c|}{ Scientific attitude } \\
\hline \multicolumn{1}{|c|}{ Aspect } & Female & \multicolumn{1}{c|}{ Male } \\
\hline Curiosity & 73.125 & 68.75 \\
\hline Respect to the data or fact & 74 & 70 \\
\hline Discovery & 70.5 & 64.175 \\
\hline Critical Thinking & 78.84615 & 72.11538 \\
\hline Perseverance & 70 & 70.3125 \\
\hline
\end{tabular}

The data was divided into two groups that explain about score between male and female. Scientific attitude is an illustration of indicators from various dimensions such as curiosity, respect to the data or fact, discovery, critical thinking, and perseverance.

TABLE V. T-TeST ANALYSIS OF SCIENTIFIC ATtITUDE SCORES AMONG MALE \& FEMALE STUDENTS

\begin{tabular}{|c|l|l|l|l|}
\hline \multicolumn{5}{|c|}{ Group Statistics } \\
\hline \multirow{2}{*}{$\begin{array}{c}\text { VAR } \\
\mathbf{0 0 0 0 1}\end{array}$} & Gender & Mean & Std. Deviation & Sig 2 tailed \\
\cline { 2 - 5 } & Female & 73.29 & 3.535 & 0.076 \\
\cline { 2 - 5 } & male & 69.07 & 2.989 & 0.077 \\
\hline
\end{tabular}

Based on Table 5, the data shows that the t-table is more than $\mathrm{t}$ count which means Ho rejected. So, there exists a significant difference in scientific attitude between male and female students. It means there is a difference between average male and female students. The group statistics table shows that the mean for female students is 73.29 , and the male students is $69,07$.

Many factors that influence scientific attitudes are (1) internal factors, namely factors that originate from within themselves which include physical and psychological factors and (2) external factors namely factors that originate outside of themselves include environmental factors and social factors.

In this case, the male students are more active than the female students. Most of the male students in this class observed the small creature more often than female. They were more curious about it. Some of them asked the assistance and the lecturer when the class ended.

Attitude is something can be learned and trained. Attitude determines how individuals react to the situation. It was explained earlier that scientific attitudes strongly support student learning activities in a positive direction. The difference of students' attitude looks explicit in all activities in the class [8]. It can be compared in a big and small class discussion. The interest and the achievement of the male students' will be better compared with female students using many activities and media of science in the class. Another factor is social factors involving social and cultural influences. Social factors are as one of the external factors that influence the concentration of students such as a conducive learning atmosphere such as being far from noise. The internal factors include women who tend to have a higher level.

\section{CONCLUSION}

The results of the study show that the scientific attitude aspects such as curiosity was categorized medium, respect to the data aspect was categorized medium, and critical thinking and perseverance were categorized medium. The highest score was discovery aspect and it was categorized high. There is a difference of scientific attitude between male and female students in Plant Botany I course.

\section{REFERENCES}

[1] G. Kaur, "Scientific attitude in relation to critical thinking among teachers," Educationia Confab, vol 2, no.8, pp.24-29, 2013.

[2] K. J. Olasehinde and R. A. Olatoye, "Scientific attitude, attitude to science and science achievement of senior secondary school students in Katsina State, Nigeria," Journal of Educational and Social Research, vol. 4, no. 1, pp.445, 2014.

[3] C. Sexton, and T. Franklin, Teaching Science for All Children: Inquiry methods for constructing understanding. Allyn \& Bacon, 2005.

[4] P. Bundu, Penilai an Keterampilan Proses dan Sikap Ilmiah Dalam Pembelajaran Sains - SD: Jakarta. Depertemen Pendidikan Nasional, 2006.

[5] A. Sudijon, Pengantar Statistik Pendidikan, Jakarta: Raja Grafindo, 2009.

[6] D. Page, and A. Mukherjee, "Promoting critical-thinking skills by using negotiation exercises," Journal of education for business, vol. 82, no. 5, pp. 251-257, 2007.

[7] N. Revati, and K. P. Meera, "An Investigation of Scientific Attitude among Secondary School. Students in Kottayam District of Kerala," 
IOSR Journal of Research \& Method in Education (IOSR-JRME), vol. 7, Issue 1, Ver. III, 2017.

[8] S. Yamtinah, M. Masykuri, A. Ashadi, and A. S. Shidiq, " Gender differences in students' attitudes toward science: An analysis of students' science process skill using testlet instrument," In AIP Conference Proceedings AIP Publishing, vol. 1868, no. 1, p.030003, 2017. 